\title{
Kevin Symonds, On the Third Part of the Secret of Fatima (St. Louis, MO: En Route Books and Media 2017). Ss. 582. \$26,95. ISBN 978-1-950108-23-7
}

\section{DAWID MIELNIK}

Katolicki Uniwersytet Lubelski Jana Pawła II mielnikdawid@gmail.com, ORCID: 0000-0002-2701-4889

W 2017 roku Kevin Symonds opublikował monografię On the Third Part of the Secret of Fatima. Opracowaniem publikacji zajęło się wydawnictwo En Route Books and Media, dając do rąk czytelników potężną, liczącą 582 strony monografię poświęconą problematyce objawień fatimskich, a zwłaszcza kwestii trzeciej tajemnicy fatimskiej. Obok wersji papierowej przygotowano również e-book dostępny na czytniki Kindle.

Chociaż od wspomnianej publikacji Symondsa minęło już kilka lat, to jednak z kilku powodów warto sięgnąć do tej monografii. Po pierwsze, autor podejmuje temat trzeciej tajemnicy fatimskiej z perspektywy osoby przyjmującej tezę o opublikowaniu w 2000 roku całości sekretu, co przez środowiska tradycjonalistyczne, a zatem przywiązane do liturgii i nauczania przedsoborowego, jest mocno kwestionowane. Jako że zwolennicy stanowiska oficjalnego, tj. przyjmowanego przez Stolicę Apostolską, niechętnie publikują teksty polemiczne, każda pozycja, a zwłaszcza monografia, poświęcona trzeciej tajemnicy fatimskiej z tej perspektywy jest cenna.

Po drugie, Symonds podejmuje merytoryczną polemikę z argumentami środowisk tradycjonalistycznych, przy czym nie jest to powtarzanie utartych sloganów czy udawanie, że problem nie istnieje, lecz przywołanie tych argumentów i ustosunkowanie się do nich w taki sposób, by bronić oficjalnego stanowiska Stolicy Apostolskiej w sprawie trzeciej tajemnicy fatimskiej.

Po trzecie, publikacja na gruncie polskiej teologii jest mało znana. Generalnie w literaturze polskiej tematyka trzeciej tajemnicy fatimskiej pojawia się sporadycznie, a czytając artykuły poświęcone tej problematyce, odnosi się wrażenie, że autorzy nie są świadomi całej masy problemów związanych z tzw. wizją biskupa w bieli. Jest to o tyle zastanawiające, że polskich publikacji poświęconych w ogóle objawieniom fatimskim jest naprawdę sporo. Sięgnięcie do publikacji Symondsa winno być wręcz obowiązkowe dla autorów, którzy chcieliby się aktywnie włączyć w bardzo złożoną dyskusję na temat trzeciej tajemnicy fatimskiej. Książka Symondsa wraz z ostatnio opublikowaną monografią $\mathrm{w}$ języku polskim, poświęconą temu problemowi (D. Mielnik, Śledztwo w sprawie sekretu fatimskiego. Czy w Fatimie Maryja ostrzega- 
ła przed Soborem Watykańskim II i nowa Mszą?, Lublin: Wydawnictwo KUL 2020), ufajmy, ożywi dyskusję również na gruncie rodzimej teologii.

Publikacja Symondsa składa się z trzynastu rozdziałów poprzedzonych wstępem (s. 11-16) i zwieńczonych epilogiem (s. 338-340), a dodatkowo z dziesięciu apendyksów (s. 341-561) oraz dość obszernej bibliografii (s. 562-580). Okładka zaprojektowana została starannie i przyciąga wzrok potencjalnego odbiorcy.

W rozdziale pierwszym (s. 17-58) autor przybliża odbiorcy faktografię fatimską. Prezentuje wybrane wydarzenia i okoliczności, które doprowadziły w XXI wieku do konfliktu w zakresie faktycznej zawartości trzeciej tajemnicy fatimskiej. Rozdział drugi (s. 59-84) stanowi próbę przybliżenia i odparcia jednego z ważniejszych argumentów zwolenników istnienia dwóch części sekretu, a mianowicie problemu objętości tajemnicy. Symonds próbuje z jednej strony wytłumaczyć, skąd wzięło się przekonanie o tym, że trzeci sekret fatimski został spisany na ok. 20-25 linijkach tekstu, $\mathrm{z}$ drugiej usiłuje wykazać, iż faktografia potwierdzająca ten przekaz nie jest pewna, a zatem nie może służyć jako argument.

Rozdział trzeci (s. 85-102) poświęcony jest szczegółowej analizie wykładów kardynała Alfredo Ottavianiego na temat trzeciej tajemnicy fatimskiej. Symonds zestawia różne wersje jego przemówienia i pokazuje różnice, do jakich doszło w tłumaczeniach. Podjęte tu analizy są niezwykle cenne, ponieważ wystąpienie Ottavianiego z 1967 roku jest podstawą do tworzenia różnego rodzaju argumentów przez zwolenników tezy o istnieniu nieopublikowanej części tajemnicy. W rozdziale czwartym (s. 103-119) autor mierzy się z problemem zapowiadanej daty publikacji trzeciej tajemnicy fatimskiej (1960) i próbuje ustosunkować się do tego, czy data ta istotnie została wskazana przez Matkę Bożą, czy może wymyślona przez samą s. Łucję.

Rozdział piąty (s. 120-147) poświęcony został analizie spotkania s. Łucji i Augustyna Fuentesa w 1957 roku. Autor bada różne przekazy dotyczące tego wydarzenia i stara się ustalić wiarygodność kluczowych sformułowań (rzekomo) użytych podczas tego spotkania. W rozdziale szóstym (s. 148-163) Symonds odnosi się do problemu przerażającego charakteru sekretu. Usiłuje pokazać, skąd wzięło się takie przekonanie, które stanowi jedną z przesłanek odrzucania mało przerażającej wizji biskupa w bieli jako (pełnej) trzeciej tajemnicy fatimskiej.

Rozdział siódmy (s. 164-172) poświęcony został komunikatowi z 1960 roku, w którym poinformowano opinię publiczną o decyzji niepublikowania trzeciej części tajemnicy fatimskiej (wbrew woli Matki Bożej). Autor zestawia ze sobą oryginał i tłumaczenia tego komunikatu, zwracając uwagę na pewne niuanse językowe. W krótkim rozdziale ósmym (s. 173-180) podjęty został temat odizolowania s. Łucji od świata zewnętrznego i uniemożliwienia jej składania osobistych świadectw wobec opinii publicznej. Autor próbuje pokazać, że s. Łucja nie tyle znalazła się w klauzurze klasztornej jako „niewygodny świadek”, ile raczej ułatwiono jej prowadzenie życia kontemplacyjnego. 
W stosunkowo obszernym rozdziale dziewiątym (s. 181-216) podjęty został temat jednego z najważniejszych argumentów przywoływanych przez zwolenników istnienia dwóch części sekretu, a mianowicie kwestia słynnego zdania o zachowaniu dogmatu wiary w Portugalii. W tej części publikacji autor próbuje zneutralizować niemal powszechnie przyjmowany sens tej frazy i usiłuje wykazać, że odnosi się on nie do apostazji, ale do prześladowań w Rosji. Równie obszerny rozdział dziesiąty (s. 217-255) podejmuje problem odwoływania się przez kard. Josepha Ratzingera do Edouarda Dhanisa w komentarzu napisanym w 2000 roku. Symonds usiłuje pokazać, że przy tym konkretnym odwołaniu Ratzinger nie odnosił się do nieprzychylnych opinii Dhanisa na temat Fatimy ${ }^{1}$, ale nawiązywał do innych twierdzeń tego autora.

Rozdział jedenasty (s. 256-292) poświęcony został próbie wytłumaczenia ewentualnych sprzeczności pomiędzy słowami Ratzingera z 2000 roku a jego przemówieniami z 2010 roku, kiedy to jako papież podjąl pielgrzymkę do Fatimy. Symonds usiłuje wykazać, że tak naprawdę Benedykt XVI nie przeczył sam sobie, a jego pozornie niezgodne wypowiedzi dotyczyły dwóch zupełnie różnych kwestii. W rozdziale dwunastym (s. 293-311) podjęty został ważny temat świadectwa Ingo Döllingera w sprawie faktycznej zawartości trzeciej części sekretu fatimskiego. Autor usiłuje pokazać, że zachowane w tej materii przekazy nie są wewnętrznie spójne, a przez co nie mogą być w pełni wiarygodne.

Wreszcie trzynasty rozdział pracy (s. 312-337) pomyślany został jako miejsce na nieporuszone wcześniej tematy. W tej części Symonds podjął m.in. problem daty zapisania trzeciej tajemnicy fatimskiej w kontekście listu s. Łucji do biskupa da Silvy z dnia 9 stycznia 1944 roku; problem użytej nomenklatury na kartce, na której zapisana została trzecia część sekretu; kwestię jednego z oświadczeń przełożonych zakonu, w którym przebywała wizjonerka; zagadnienie wypowiedzi Ratzingera z 1984 roku oraz kard. Angelo Sodano z 2000 roku; temat zapoznania się z trzecią tajemnicą fatimską przez Jana Pawła II w kontekście decyzji o poświęceniu świata Niepokalanemu Sercu Maryi.

Liczba rozdziałów recenzowanej monografii zapewne miała nawiązywać do trzynastego dnia objawień fatimskich, a zwłaszcza 13 lipca, kiedy to Maryja przekazała dzieciom trzecią tajemnicę fatimską, która jest centralnym tematem tej publikacji. Tego rodzaju zabiegi literackie wiążą się z ryzykiem niewłaściwego doboru treści, niezachowaniem wewnętrznej spójności dzieła albo niewyczerpaniem tematu. Teoretycznie ostatni rozdział publikacji został pomyślany jako swoistego rodzaju część

1 Eduardo Dhanis był zwolennikiem rozróżniania pomiędzy tzw. Fatimą I oraz Fatimą II. Owa dywersyfikacja służyła uzasadnieniu, że nie wszystko, co s. Łucja przekazała światu, rzeczywiście musiało pochodzić od Maryi. Nie wnikając w daleko idące konsekwencje tego rozróżniania, na potrzeby niniejszego tekstu warto jedynie zauważyć, że według zwolenników istnienia niepublikowanej części sekretu, taka dywersyfikacja umożliwia Stolicy Apostolskiej „legalne” usunięcie treści, które są dla niej niewygodne. Tak więc powoływanie się Ratzingera na tego autora, który dał solidne podstawy do przesiewania treści objawień fatimskich, jest zdaniem niektórych osób bardzo podejrzane. 


\section{DAWID MIELNIK}

ogólna, w której można umieścić niewykorzystane wcześniej treści, ale w praktyce to rozwiązanie ma swoje wady, chociażby uniemożliwia szczegółowe przebadanie poruszanych w tym rozdziale kwestii.

W przypadku monografii Symondsa zaproponowane rozwiązanie podziału omawianych treści nie do końca zdało egzamin. Można się zastanawiać nad połączeniem niektórych rozdziałów (np. drugiego z trzecim czy dziesiątego z jedenastym), aczkolwiek zasadniczy problem leży zupełnie gdzie indziej. Otóż jest kilka wątków, których na pewno w tej publikacji zabrakło. Symonds nie odniósł się choćby do niezwykle ważnego dokumentu kard. Lorisa Capovilli, będącego jednym z najważniejszych argumentów za istnieniem dwóch części sekretu fatimskiego. W ogóle nie zajął się szczegółową analizą wystąpienia kard. Tarcisio Bertone w programie „Porta a Porta”, a zwłaszcza pokazanymi wtedy kopertami, które w bardzo mocny sposób potwierdzają słuszność zarzutów kierowanych wobec Stolicy Apostolskiej przez zwolenników istnienia nieopublikowanej części sekretu. Monografia nie zawiera żadnego odniesienia się do świadectw takich osób, jak o. Malachi Martin, kard. Mario Luigi Ciappi, kard. Silvio Oddi czy ks. Tomasz Jochemczyk. Nawet jeżeli ten ostatni mógł być nieznany autorowi, to wypowiedzi wcześniej wymienionych autorów na temat zawartości trzeciej tajemnicy fatimskiej Symonds musiał znać. W żaden sposób autor nie ustosunkował się również do problemu dwukrotnego zapoznania się z trzecią tajemnicą fatimską przez Jana Pawła $\mathrm{II}^{2}$. To są tematy, którym można było poświęcić odrębne rozdziały, co jednak w konsekwencji naruszyłoby przyjętą odgórnie strukturę trzynastu rozdziałów.

Obok głównej zawartości na publikację - jak wspomniano - składa się również szereg apendyksów. Symonds przedstawia w nich wypowiedzi kard. Ottavianiego na temat trzeciej tajemnicy fatimskiej; transkypt z rozmowy kard. Capovilli z Marco Roncallim z 1994 roku; transkrypt konferencji z 26 czerwca 2000 roku; transkrypt z programu „Porta a Porta”, w którym kard. Bertone pokazał do kamer manuskrypt wizji biskupa w bieli; wywiad Fuentesa z s. Łucją oraz kilka tekstów samego Symondsa, opublikowanych przy innych okazjach.

Bibliografię recenzowanej publikacji, obok książek, w znacznym stopniu tworzą różnego rodzaju zasoby internetowe, czego jednak nie należy traktować jako metodologiczny błąd autora. Faktycznie dyskusja na temat trzeciej części sekretu fatimskiego w ostatnich czasach przeniosła się przede wszystkim do przestrzeni internetowej, stąd nieuwzględnianie publikowanych tam tekstów po prostu nie dałoby autorowi pełnego wglądu w podjętą problematykę.

Czy publikację Symondsa warto polecić? Na tak postawione pytanie należy odpowiedzieć twierdząco. Autor nie powtarza już funkcjonujących treści dotyczących trzeciej tajemnicy fatimskiej, ale stara się rzucić nowe światło na toczącą się dysku-

2 Autor nawiązuje co prawda do odczytania tajemnicy po zamachu, ale w zupełnie innym kontekście, bez odniesienia się do tego, że Jan Paweł II miał zapoznać się z trzecią tajemnicą fatimską jeszcze w 1978 roku. 
sję. Bardzo cenna jest treść załącznika „D”, w którym autor umieszcza zapis bardzo trudno dostępnego wystąpienia kard. Bertone w programie „Porta a Porta”. Dodatkowy walor publikacji zapewnia to, że autor odnosi się do różnych zarzutów formułowanych względem oficjalnego stanowiska Stolicy Apostolskiej w sprawie upublicznienia trzeciej tajemnicy fatimskiej i próbuje je zbić, broniąc tym samym tezy, że w 2000 roku Watykan opublikował całość sekretu. Czy jednak robi to w sposób przekonujący? W opinii recenzenta - nie. Na taką ocenę składa się kilka czynników. Po pierwsze, Symonds w niektórych rozdziałach swojej publikacji podaje alternatywne wytłumaczenia problemów związanych z trzecią tajemnicą fatimską. Czyni to zawsze na korzyść oficjalnego stanowiska Stolicy Apostolskiej, jednak nie troszczy się w sposób należyty o to, żeby wykazać, że proponowane przez siebie rozwiązania są lepsze od interpretacji drugiej strony sporu. Po drugie, autor nie uwzględnia w monografii kilku bardzo ważnych wątków (wspomnianych powyżej), które w istotny sposób mogą wpływać na wynik prowadzonych analiz. Po trzecie, już na początku publikacji Symonds proponuje bardzo wątpliwą metodologię w zakresie przyznawania wiarygodności posiadanym materiałom dowodowym. Polega ona na uznawaniu za prawdziwe oświadczeń świadka (których sam świadek w żaden sposób nie dokumentuje) na niekorzyść publicznie dostępnego dokumentu potwierdzającego tezę przeciwną. Wszystkie te mankamenty razem wzięte w opinii recenzenta sprawiają, że autor broni swej tezy w sposób nieprzekonujący dla krytycznego i obeznanego z tematyką czytelnika. 
